\title{
化学物質総合管理の今後の展開 \\ 一自主管理と人材育成一
}

\section{東京農工大学工学部 増 田 \\ Future Development in Comprehensive Risk Management of Chemical Substances -Self-Management and Human Resource Enrichment-}

優

Masaru Masuda, Ph. D.

Faculty of Engineering. Tokyo University of Agriculture \& Engineering

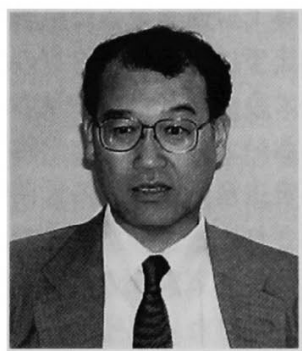

Discussions on risk management of chemical substances have been repeated among international organizations such as OECD from $1970^{\circ}$ s, and have resulted in establishing various concepts, principles and systems. Based on such trends. I have proposed a concept of "Comprehensive Risk Management of Chemical Substances" making full use of scientific knowledge and logical thinking. Self-management, mainstay of the concept of "Comprehensive Risk Management of Chemical Substances," has achieved great result.

Future trend can be predicted by observing the activities of the international organizations, and through logical thinking based on scientific knowledge. First come will seize the opportunity and contribute to positive growth in management.

Construction of new science on "Comprehensive Risk Management of Chemical Substances" that discuss such matters from a bird's-eye point of view has been attempted, and human resource enrichment based on this new science is enfolding.

分類 : $\mathrm{X}_{1}$ 環境総論, $\mathrm{X}_{2}$ 紙パルブ産業環境一般

1.はじめに

一化学物質管理の基本的な考え方一

先般, 化学物質審查規正法が改正された。これに限 らず，近年化学物質管理に関する諸々の動きがある。 化学物質管理をめぐるこうした動きの要点の一つは, こうした事柄は急に起こったわけではなく 10 年も 15 年も前から予見できたということである。国際的な， あるいは国内的な動きを見て，かつ，論理的に思考す ると必ずこうなると 10 年も 15 年も前から予測できた。
そして、これからもっと多くのことがどんどん起きて くることも予見できる。物事を論理的に考え，前に前 に準備することが重要である。

それから，二つ目は，化学物質管理をコスト要因， コスト・センターというとらえ方ではなく, プロフィ ット要因, プロフィット・センターとしてとらえてい くことである。論理的に考えて先に準備している人は， プロィット要因, プロフィット・センターとしてう まく活用し, 対応が遅れた人は, コスト要因, コスト ・センターとして苦労する。 
2003 年春, 「化学物質橎査規正法」が改正された。 1973 年に化学物質審查規正法が制定され, 1986 年に一 度改正された。今回の改正は，これをはるかに上回る 抜本的な改正である。ほとんど新規立法に等しい大き さを持った改正である。法律は，目的を変えることは 実質上，新規立法としての扱いを受けることになる。 今回の法改正は, 目的を変えたという点では, 明らか に新規立法ととらえてよい。では，何が新規立法なの か,あるいは，何がそれほど大きなことなのか。

この法律の改正で，人への影稫だけではなくて，環 境生物への影製も对象に入ったことが第 1 である。し かし，それ以上に大きなことは既存化学物質の扱いで ある。これまでは既存化学物質の点検は国の賣䅂であ つた。そのようなことは今の世の中では通らない。つ いに日本においても, 既存化学物質についても, 基本 的にはそれを生産し販売する民間の責任であるとの一 歩が踏み出された。これが第 2 である。第 3 の主要な 改正点は，化学物質管理を考えるときの基本的な考え 方として，リスクという考え方に基づくべきたという ことを明確にしたことである。化学物質審査規正法自 身がリスク原則にのっとった体系になっていなかった 部分があり，その調整が図られた。

しかし，これらの改正のいずれもが 10 年ほど前か ら予見されたことである。ビジネスチャンスとするか 否かは人によって企業によって異なる。

ここで新たに一つ付け加えておきたい。化学物質管 理をきちんとする上で，企業にも役所にもこのような ことをきちんと動かしていく人材が足りないことであ る。化学物質管理の基本的な考え方を理解し，それゆ えに予見能力を発揮できる人材が不足している。この ことが非常に大きな事項として浮かび上がってきてい る

今まで個别にばらばらと論じられ，あるいは，それ ぞれの分野で行われてきた化学物質の管理が，一つの 「化学物質総合管理」というコンセプトのもとにまと められ，それにあった新しい知識体系が侴られ，新し い学問が創られていくプロセスに今や入りつつある。 それを受けた形で、「化学物質総合管理」をプロフェ ッショナル（専門職業人）として扱う人材の育成とい うことが, 議論の対象になりつつある。

物事を科学的に論理的に考えることが過去の動きを 大局的にとらえ将来を見通すうえで最も重要な方法で ある。加えて，化学物質管理は世界的な動向に連動し て動いてきているわけで，世界的な動きを見ていれば そこに潜んでいる科学的なものの考え方や重要な見方 がわかり，将来を予見することができる。そうしたこ
とのできる人材が必要である。

従来は, 労働安全は労働安全, 食品安全は食品安全, あるいは製品安全は製品安全, 公害は公害として扱わ れてきた。しかし，「化学物質総合管理」というとら え方の中で，化学物質に係る物事を全体として見てい く必要があるということが世界的な流れになってきて いる。したがって，世界的な流れの「化学物質総合管 理」とはどのような考え方であり，いかなる基礎のも とで論じられているのかを認識することが必須である。 そして，「化学物質総合管理」は，個別の法律の議 論を越えて自主管理, あるいは, 自主的な経営という ところに進んでいく。「化学物質総合管理」の流れを 予見・予測しながら，事前に手を打って，一つの立場 をうまく作り上げた人が非常に強い立場に立つ。

\section{OECD の活動}

\section{一化学物兵管理をめぐる国際的な展開一}

国際的な動きの中で OECDの動きは先導役として の意味をもつ。OECD では 1975 年から, 8 年ごとに第 1 期, 第 2 期, 第 3 期ということで活動を展開をして きている。科学的な知見をきちんと集めるため, 科学 的手法を作るところから始まって, 次にそこで得られ た情報をきちんと有効に活用していくための方策を考 え，そして具体的にリスクを管理し削除していくため の試みを行った。るれらをさらに継続しながら，その ような積み上げを踏まえて次のステップに入っていっ た。非常に論理的に物事が進んできている。

OECD の活動の目標は, 健康影䱥の未然防止であ り，貿易障害の未然防止ということである。未然防止 という考え方は, 科学的な知見のもとに科学的, 論理 的に思考することを基礎にしてはじめて可能となる。 よく「未然防止」ではなくて，「予防原則」と言う人 がる。予防原則というのはあいまいな言葉でよく分 からないが，予防原則というものを非常に突き詰めて いくと，要は「何もしない」という答えになりかねな い。結果として化学物質は使わないということになり かねない。化学物質を使わなければ，そのリスクはゼ 口で最低であることは間違いない。でも，それが可能 であるか, 或いは妥当であるかである。一方，未然防 止という考え方は，サイエンスの知見と論理的な思考 方法を基礎に，事柄を未然に防止していくということ である。それは, レギュラトリー・サイエンスという 領城が確立してきた過程を尊重することである。

試験方法を作るところから始まって，データの信頼 性の確保に関する規篹を作り，さらにリスクを管理す る上で，市場に出す前に最小限，最初どれたけの試験 
をすればよいのかということも決めてきた。実は，こ の過程で，澎大な数の専門家や人々が議論をしてきた。 例えば，OECD が策定した試験方法だけでも 100 を 越える。今でもどんどん見直され改善され，そして新 しい試験方法が追加されている。その試験方法一つ作 るにも，各国の専門家が集まり，何年もかけて議論を し, 最後は各国, 各試験機関で実際に試験をしてみて, みんな同じデータが出るかどうかを確認するところま で行われている。そのような過程で，いろいろな議論 やいろいろなやり取りが蓄積されて, 次の展開にどん どんつながっていく。

このような活動というのは, 決して国の機関だけが 参加するわけではなく, NGO も参加できる。産業界 も学界も労锄界も，あるいは日本流にいう NGO, い わゆる市民運動もみんな NGO として参加できる。こ のようなことを論じるに足るだけの科学的な知見と, かつ, 科学的, 論理的に思考し詥しる資質を持ち合わ せれば，だれでも参加できる。そのようなところに参 加して，物の考え方を磨くことは非常に重要なことで ある。そのような膨大な積み上げが, 1975 年から 8 年 間行われ，それが今でも継続されている。例えば，テ スト・ガイドラインは、どこかの国なり，どこかの NGO なりが提起したものが，世界的な議論のプロセ スを経て，国際的な統一方法になる。正にテファクト ・スタンタードになる。これは試験方法についての一 例だが,レギュレトリー・サイエンスはこうして，人 類が知恵を結集してつくりあげてきた。

さて，環境生物への影車が化審法の改正によって対 象に入った。環境生物への影靁を見るために, 代表と して三つの試験をやることになっている。ミジンコに 関する試験，藻に関する試験，それからメタカに関す る試験である。ミジンコに関する試験について，日本 にいないミジンコを使うとなると，日本の風土に合わ ないミジンコを飼っていくだけでも大変である。デフ アクトを取れるか取れないかの違いというのはそのよ うなことにもある。生物浱維性試験をやるときは, 日 本が提案したものが国際的なスタンタードになってい るので，日本で一番ボピュラーな魚を使えばいいこと になっている。

OECDのテスト・ガイドラインのうち，いかにも 寂しいことだが日本からの提案は三つしかない。この ような環境や安全の分野なら, 厚生省, 労動省, 環境 庁, あるいは環境問題に非常に熱心な大学の先生方が 提案してしかるべきであるが, なぜか三つとも通産省 の提案である。日本提案の毒性試験が一つもないのは さびしい限りである。今, 期待をもてる状況が出てき
ている。内分泌掼乱物質に関連して OECD で，最終 的に幾つかの試験方法が候補として絞り込まれている が，日本から提起した方法がかなり有力な試験方法と して残っている。

試験方法を構筑する過程はまさに科学的知見の基づ く論理的な思考過程である。内分泌摚乱を例にとろう。 まず, 内分泌に係るような化学物質があると, 細胞表 面にあるレセプターというたんぱく質に化学物質が結 合する。内分必港乱を疑うような物質が，本当に細胞 表面のレセプターに結合するかどうかを検証する試験 をバインディンク・アッセイという。これが一つ目の スクリーニング試験方法になる。次に, レセプターに 結合すると, そこからシクナルを発して, 細胞の核に ある遭伝子に伝わって, 当該部分の遭伝子が活性化す る。それが，内分泌の活動の次の基本的なメカニスム である。そうすると, 遗伝子が本当に活性化したかど うかを逆に検証すればよいことになる。これが二つ目 のスクリーニング試験方法となる。最後は, 子宮等が 大きくなったか小さくなったか, 精巣が大きくなった か小さくなったかを調べればよい。これらは確認の試 験である。これら試験がパッケージとして動いている。

そこにおける基本的な考えは，一つは，本当にそう なのかを確認するために科学的な試験方法をきちんと 確立することであり，もう一つは，指摘されているよ うな現象があるのかないのか, それをきちんとデータ を集積して検証することである。ここで指摘したいの は，上に述べたようなことが日本でそれも身近な所， 化学物質評価研究機構で行われていることである。こ うしたことが皘み上げられてグローバルなスタンター ドになる。事柄はこのような議論の中から作られてい る。したがって，そういうサークルに入っているかい ないかが決定的な差となる。

話題を, OECD の次の 8 年間に戻すが, 試験方法 ができ，信頼に足るデータが出てくると，これをどの ように有効に活用しようか, このようなデータ，情報 を有効に使うにはどうしたらよいかということが議論 になる。ここで論理的に出てくるのは, それぞれの化 学物質固有の性質である有害性（ハザード）に関する 知見やデー夕はある意味で科学そのものであり，でき るだけ多くの人たちで共有していくことが重要だとい う概念である。そして，有害性に関する情報を広く共 有していくため, 逆に一つの州結として, コンフィデ ンシャリティー（機密性）をどのように保護するかと いう考え方が出てくる。これも含めて科学的知見の共 有化を図るための議論が行われた。そこから MSDS も始まっている。 
次に，第 1 期と第 2 期の積み上げの上に，第 3 期に は具体的にどのようにすれば化学物質のリスクを削減 できるかを論じることとなった。例えば，カドミウム の入っているパソコンをヨーロッパに輸出して, 何百 万台回収するという事件がおきた。これは，今までの 知見の蓄積を十分に理解していればそのリスクを回避 できたはずである。もう一つの例が、臭素系難燃郕で あろう。テレビのキャビネットはじめ, プラスチック 製品に入っている。それをどうするかは, すでに，大 きな課題であると同時に，明らかに今後，大きな動き となるであろう。十数年前からこの動きを予測し準備 した人と，していない人では，随分大きな違いが出る。 こうした場面でも科学的な議論をきちんと行ってきて いるサークルに入っているか入っていないかが, 将来 を読む上で非常に大きな違いとなる。

\section{3. 化学物質総合管理一新しい概念の提供一}

こうした国際的な動きや科学的な知見に基づく論理 的な思考によって「化学物質総合管理」という一つの 概念を提起した。なぜ総合なのか，その意味は何かと， いまだにこの概念を認めたくない人もたくさんいる。 例えは，琂境問題に関心の強い人は，化学物質の問題 を環境問題としてのみとらえる。それ以外のことには 関心もないし，それ以外のことが重要だということは 認めたがらない。全く同様に, 労㗢安全に関心の強い 人は，その視点でのみ化学物質をとらえる。

しかし，現実は異なる。同じ化学物質, 例えば, ベ ンゼンが、環境問題も引き起こすし，労働問題も引き 起こす。また，製品中に入っていれば，製品安全上の 問題, 消費者問題も引き起こす。そして場合によって は，互いに二律背反である。一方でベンゼンが有益な 役割も果たしている。その全体を捉えるという意味で， 「化学物質総合管理」という概念は, 非常に重要な一 つの概念提起である。

では, 総合管理の総合とは何か。まず, 総合の意味 の一つは，すべての化学物質を対象とすることである。 PRTR 制度の対象化学物質は 300 余, MSDS 制度は 400 余である。しかし，それ以外の化学物質でも必ず 何らかの固有の有害性があって影锌がある。その意味 では，すべての化学物質が対象である。かつ，二つ目 に，すべての特性を対象とすることが原点になる。さ らにすべての視点ということが重要である。

視点というのは, 人間の知恵の集積とともにどんど ん增えてきた。まず最初は，労䣦安全の梘点が問題に なった。その後消費者に対する安全等々, 人間の知見 が增えるに従ってずっと增えてきた。ついには，人へ
の影響だけではなくて，環境生物への影響に広がり， さらには, 地球の環境そのものが変わることが対象と なってきた。また, 科学の進展によってそれまで知ら れていなかった内分泌拍乱というような現象が指摘さ れ，それが確認されれば，これもまた視点として対象 になっていく。したがって, 科学の発展, あるいは人 類の科学的知見の増大に従って, 視点はどんどん広が っていく。

このように, 科学の発展だけではなくて, 科学の発 展によってもたらされた知見を国民が重要だと思えば， 化学物質管理の視点はどんどん膨らんできたし，これ からも膨らんでいく。

このように化学物質総合管理ではすべての化学物質 を対象に，すべての特性を視野に入れて，時代の流れ ととも視点が拡大していく。そのように考えると, 当 然のこととして, 化学物質のすべての用途が議論の対 象になる。そして, これは化学会社だけの範囲で考え られるわけではない。化学物質はいろいろな形で使わ れている。テレビになったり，おもちゃになったりし て，そして最後は廃棄される。これに係わるすべての 関係者が化学物質にかかわりを持つことになる。化学 物質総合管理は用途においても関係者においても総合 的である。

化学物質総合管理の基本的な考え方で重要なのは, 「リスク原則」である。レギュラトリー・サイエンス の進展や国際的論議の進展を踏まえ, 加えて科学的知 見に基つくく論理的思考の結果として「リスク原則」と いう言葉を提起した。「リスク原則」とは，リスクと いう考え方をべースに物事を判断していくということ である。リスクという考え方は，「ハザード」すなわ ち有害性等の化学物質固有の性質というものを基碳に しながら，しかし，それだけで判断するのではなく， どれだけその化学物質に暴露するかを加味して, 実際 どのくらい危険性（リスク）があるかを判断するとい うことである。そして,リスク評価した上で問題があ る水準であれば,リスクの軽減を図り、リスクを管理 していく。

例えば，A 化学物質は発ガン性があるとする。し かし，もし，それに暴露することがなければリスクは ゼロであり，何の問題もない。暴露の内容やレベルに よって対処する方法と程度が決まる。これが「リスク 原則」である。

香料会社が香料を作って食品会社に販売し, 食品会 社が食品添加物としてそれを食品に入れたとする。そ の香料の中に B 化学物澌が微量に入っていたとする。 それは法律上禁じられていたとする。したがって，そ 
の香料が添加されていた食品はすべて回収されたとす る。日本の社会では当たり前に起こりそうなことであ る。しかし，最新の科学的知見に基づいて各国では $\mathrm{B}$ 化学物質は規制対象からはずしていた。日本だけが規 制対象物質として残ったままであった。しかし，法律 は法律で，これを使ったことは法律違反である。それ が引き金となって，食品の回収の動きが広がったとい う想定である。当然回収による負担で, 香料会社は倒 産し従業員は失業するという想定が含まれる。

多分アメリカであれば行政訴訟が起こって，最新の 科学的知見に基づかない行政として法律规制当局が敗 訴するかもしれない。そこが第一の論点である。次に， 香料に入っている $\mathrm{B}$ 化学物質はごく微量である。そ してその香料は食品にほんの微量しか添加されない。 したがって, 食品に入っている B 化学物質はもっと 微量になる。そのリスクをどう考えるのか。全国の小 売店から全製品を回収することが必要なリスクの水準 なのか。第二の論点である。

このようなことをきちんと世の中で議論する必要が ある。法律違反というのと同時に，それが持っている 意味を論じる必要がある。このリスクという考え方は, 非常に重要な考え方であるが，日本ではなかなか根付 かない。同様に最新の科学的知見に準拠した論理的な 行政という考え方も日本では根付いていない。

\section{4. 自主管理の意味}

\section{一化学物質総合管理の新展開一}

ハザードは科学的なデー夕で，人類共通な知見であ る。一方で, 暴露というのは, ケース・バイ・ケース, 場面場面で違う。暴露が㐿ってくるリスクの評価や管 理も千差万別である。政府がやるというのは基本的に 無理がある。その製品を使う状態によってそれぞれ違 うリスクを国が一律に管理するというのは困難である。 基本的には，化学物質管理というのはそれぞれの場面 場面で当事者が自主的にやるべきものであるとする重 要な考え方がここから出てくる。

その自主管理を支援するのが「化学物質管理促進法」 という法律であり， PRTR 制度と MSDS 制度である。 これら両制度はもともと自主管理から始まったのであ る。そして，自主管理には MSDS が圧倒的に重要な 意味をもつ。化学物質を作る人は，物を作るだけでは なくて，有害性の情報をもきちんと把握しなくてはい けない。データがなければ試験をして自分で作り,

MSDSを充実しなければいけない。

既存化学物質だからといって「国の責任た」として, 必要にして十分な情報データを持ち合わせていないな
どということは許されることではない。物を売るとき に，きちんとその情報を提供していくのは当然の役割 である。中間業者, 例えば塗料業者は原料である化学 物質（化学製品）を購入する化学会社から情報はもら えばよいという考え方もあるが，恐らくそれだけでは 充分ではない。自分自身も具体的に調べて，必要十分 か検証し，充分でないと思えば，自分も追加的に試験 をして、科学的な知見を得ることが重要である。次に， おもちゃ屋さんが赤い塗料で消防車のおもちゃを作っ たとする。おもちゃ屋さんも同じょうに，使う原材料 や塗料について，有害性情報を集めると同時に，物を 売るときに消費者に伝えることが重要である。ただし， 消費者に伝えるときには，有害性情報を翻訳をして消 費者に分かるように説明する必要がある。

ここまでは，MSDSの当たり前の説明であるが， 論理的に思考するとここからもう一つのことが明らか に浮き出てくる。何となれば，化学物質の有害性に関 する情報はMSDSを通してバトンタッチされる。で も，どのくらいその化学物質が入っているかの情報は ない。塗料の中にどのような化学物質がどれだけ入っ ているのか。その情報がなければ有害性に関する情報 だけでは対処のしょうがない。そうすると，論理的㷌 結として，MSDSと同様に，化学物質がどれだけ入 っているかの情報を全部受け渡していくことが必要だ という考え方が出てくる。

今や, この考えが国際会議の議論を超えて, デファ クトとして動き始めた。自動車メーカーなどがどのよ うな化学物質が自社の製品, 例えば車に入っているか を全部把握しょうとする方向に動いている。これは, すべての部品にどのような化学物質が入っているか把 握することを意味する。世の中でどのような化学物質 がどこでどう使われてどうなっているかという情報を 全部集積することにつながる。

「この莮薬こそが、この製品の性能を決める非常に 重要な要素だから，これは教えない」などという考え 方は，恐らく全く通用しなくなる。消費者が，「使用 されている化学物質の量を足して $100 \%$ にならなけれ ばその商品を買わない」ということになる。ノウハウ を保全したいのであれば，成分を教えないことをもっ てでなく，ほかの方法で行う必要がある。今の特許法 等で保全できない分野がれば，同時並行に，それを保 全する仕組みや制度を逆に提起して創り出すというこ とが必要となる。とにかく，今までのように「教えな い」という形での対応は，恐らく成り立たなくなるで あろう。 


\section{5. 自主管理の成果}

一効果的・効率的な化学物質総合管理一

化学物質棇合管理においては，自主管理は重要な機 能をになう。それが実績を上げている例を一つ紹介す る。大気污染防止に関しての結果がそれである。自主 管理によって大幅に排出が削隇された。第 1 期（1997 年〜99 年） 3 年で $41 \%$ 削減されて，そこで，「もう， みんな, やめるのかな」と思っていると,「いや, 自 主的にもっとたくさん削隇したい」ということになり， 次の第 2 期（2001 年〜03 年） 3 年間でさらに 40 数\% 堿らすことになった。結果として, 環境省や環境保讙 に関心を持つだれも想定しなかったくらい排出が大幅 に娍ってしまった。あまり隇りすきて「環境モニタリ ングの学生実習ができなくなった」との不満の声さえ 上がったという。環境省は「自主管理でやると，だれ もまじめにやらないから，减らない」と言って规制立 法を検討していたが, まったく逆で, 大変効率的にし て効果的な成果を，自主管理は挙げたわけである。

しかし，こうした場合「このような化学物質が排出 されていた。それをできるだけ減らしてゼロにもって いく」というマイナス思考の説明がされる場合が非常 に多い。これだけでは説明として充分ではない。「リ スクの視点から見れば必ずしも必要はないが,こんな に削減する。世の中に対しプラスの環境を創っている」 というプラス思考のもののとらえ方をして, 主張して いくことが重要である。このようにプラス思考で物事 に対処し，事柄を転換していくことが非常に重要であ る

そのために何が必要か。言われてから始めると，ど んなに良いことであっても, マイナス点をゼロにしか できない。言われる前にやると，同じことをやっても， ブラス点として評価してもらえる，ということである。 そのような意味で, 未然防止とは, コスト・センター をプロフィット・センターに変えて，物事をやってい くことにも通じる。「同じことでも, コスト要因では なくて,プロフィット要因としてやっていくのが得だ」 というのか，自主管理の最も重要な意味である。

コスト要因がプロフィット要因となった例がある。 近年できた化学物質に関する国際条約にストックホル ム (POPs) 条約, ロッテルタム (PIC) 条約, TBT 条約等々がある。とりわけ，TBT 条䄪というのは， 「自主的にやると有益だ」という例示になるであろう。 TBT というのはトリフチル錫の格である。TBT 条約 が 2001 年にできて, トリフチル錫を船底塗料として 使うのを世界的にやめるということになった。
これは実は，日本が発意して，しかけてきたことで ある。なぜ，日本が発意したのか，なぜできたか。TBT は, 1989 年に第二種特定化学物質になった。第二種特 定化学物質は生産や使用は禁止でない。生産して使っ てもよい。けれどもこの塗料業界の一部の人たちが, 「生産をやめよう, 減らそう」と, 自主的にどんどん 減らしていった。そして 1999 年にはついにゼロとな った。

これだけでとどまるならば，ネガティブな対応であ る。しかし, どんどん減らしていく一方, どんどん代 替品を開発し，自らのTBT の生産が見事にゼロにな ったところで, IMO（国際海事機関）にこのことを 持ち込んで，世界的に禁止しようと動きかけた。それ から何年かして 2001 年に条䄪になった。表面を見る と, IMOに持ち込んだ運輸省が, 環境問題を訴える 旗を振って条約ができ，グローバル・スタンダードと なったように見える。その実, 塗料業界の努力の結果 である。代替品は, TBTよりも高価であるとしても， だれもそれを使わないわけにはいかない。先ほど，抽 象的に記したが，コスト・センター（コスト要因）で はなくて，プロフィット・センター（プロフィット要 因）にするという具体的な例である。「環境保護の神 様」と言われながら，利益を上げることにもなる。マ イナス点ではなくて, ゼロ点以上, プラス点の世界に なる。

6. おわりに

一化学物質総合管理をめぐる今後の課題一

自主管理が化学物睤総合管理の中心として位置づけ られると，その帰結として，化学物質管理に関する「企 業行動の評価」が行われることになる。分かりやすく 言うと化学物質総合管理をどれたけきちんとやってい るかを格付けすることになる。それによって，株価が， あるいは資金調達のコストが変わる。そのような時代 が来るであろう。これから，化学物質の問題がますま す社会の関心事として大きくなってくる。そうなると， 当然，化学物質総合管理に着目した企業行動の評価が 求められる。

マイナス点があるかないかというのは，法律を守っ ているかどうかの問題である。マイナス点はあっては ならない。法律を守るのは当然のことである。そうで はなくて，化学物質総合管理では自主管理によりプラ ス点がどれだけ上げられるかという視点が重視される。 化学物翼の管理をよりよいものに変革することを通し て社会に新たに価值を創造していく，大きな時代の転 換が起こりつつある。 
そのような文脈でとらえると, 最後に重要な課題と して人材という問題が残る。これまで記したような事 柄をうまく動かしていくある種経営的な感覚を持った 人材, 化学物質を管理するだけでなく化学物質を経営 するセンスの人材が必要である。そのためには，ただ 単に科学を知っているだけではなくて，もろもろのこ とを絵体として知っている必要がある。化学物質総合 管理や化学物質経営という観点をもってこの領域を俯 䑤的に捉え教える学問は現在大学にも存在しない。新 しい学問,「化学物質 (捴合) 管理学」といったもの を創って教育していく必要がある。

これからの時代は, この化学物質の管理の分野に限 らず，いろいろな分野で，これまでの学問が再編成さ れていく時代である。この再編においては, 社会の目 的・目標に合わせて多くの学問分野の知識を包括しつ
つ再整理・再統合することが必要である。そのような 学問がこれからいろいろな形で出てくる。その一つを 勝手に命名して,「化学物質 (総合) 管理学」と称し ている。化学物質を単にコントロール (制御・管理) していくのではなくて, マネージメント (経営) して いくというところにまで, 発展させる必要がある。 お䒩の水女子大学でライフワールド・ウオッチセン ター（LWWC）が設立されたのをはじめ,化学物質 の管理・経営に関する専門職業人の育成や化学物質に 係わる 21 世紀の新たな教養教育を推進する挑戦が 着々と進んでいる。そして，人材を育成するためにも， 学問的な背景なしに人材を育てることは不可能である。 「化学物質 (総合) 管理学」という学問の創出から着 実にやっていかなければならない。 


\section{報 文 概 要 一 勧}

\section{企業における京都議定書対応戦略}

三美総合研究所 西村 邦幸

京都議定夆は 2004 年までには発効すると予想される。その場合日本では第一約束期間（2008～2012） に 1990 年のレベルから, 温室効果ガス排出を $6 \%$ 減少させることを要求されることになる。仮に国内 の手段でのみこれを達成しようとすると，日本の産業界にとって大きな負担になると考えられる。既に 高度な省エネ対策，すなわち $\mathrm{CO}_{2}$ 削減策が謱じられてきたことが理由である。本報は，京都議定晴に 対応するために将来の企業戦略を検討することの重要性について述べる。

(本文 40 ページ)

\section{化学物質総合管理の今後の展開 \\ 一自主管理と人材育成一}

東京晨立大学工学部 增田 優

1970 年代から OECD などの国際機関において化学物質管理に関する論議が皘み上げられ，種々の考 え方や原則，そして制度が制定されてきた。こうした動向を踏まえつつ，科学的知見と論理的な思考を 基本とする「化学物質捴合管理」という概念を提起した。「化学物質総合管理」に基づく活動の柱のひ とつが自主管理であり，大きな成果を上げてきた。

今後の動向は，国際機関の動き見つつ，科学的知見に基づき論理的に思考をすることによって予見可 能である。先んじた者が機会を制し，経営にプラスに転化することができる。

こうした事柄を侑酷的に論じる学問として「化学物質（緿合）管理学」の構築が試みられ，それに基 つ゚く人材育成が始まりつつある。

(本文 43 ページ)

\section{PRTR 等，情報公開に伴う企業の対応}

\section{ケミカルリスク研究所 星川 欣芓}

我が国の PRTR 制度は，「特定化学物質の桭境への排出量の把暒等及び管理の改善の促進に関する法 律 (化学物質管理促進法)」によって等入され，その第 1 回雀計・推㖕データが本年 3 月 20 日に公表さ れた。NGOサイドでは，横浜国大の浦野教授らや有害物質削娍ネットワークが PRTR データを活用し て，事羓者に排出量の削娍を促す活動を予定している。

こうした状況を踏まえて，ここでは，化学物澌管理促進法の目的，化学物質リスク管理の留意点，お よびリスクコミュニケーションの留意点に間する私見を述べる。それぞれのポイントは，法律で規定さ れる「化学物質管理指針」に留意した薏切な自主的管理，管理目標値の自主的設定における科学性の追 求および蔺連政府機関における科学的りスク論に基づく化学物質管理への率先的取り組みの必要性で ある。

(本文 50 ページ) 